International Journal of Management and Sustainability

2021 Vol. 10, No. 3, pp. 69-78.

$\operatorname{ISSN}(e):$ 2306-0662

$\operatorname{ISSN}(p): 2306-9856$

DOI: 10.18488/journal.11.2021.103.69.78

(C) 2021 Conscientia Beam. All Rights Reserved.

check for
updates

\title{
ASSESSING BANKS' MANAGERIAL EFFICIENCY DURING THE COVID-19 PANDEMIC: EVIDENCE FROM SELECTED NIGERIAN BANKS
}

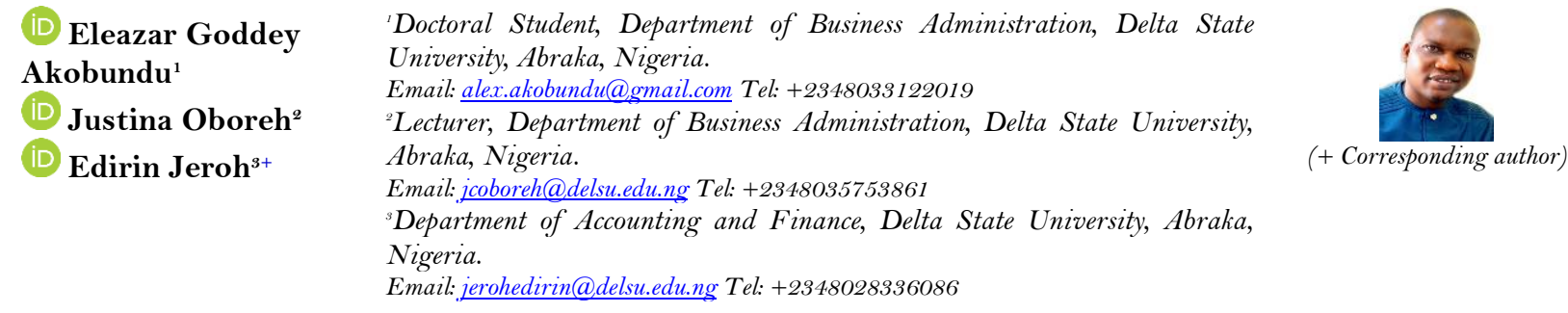

Article History

Received: 21 June 2021 Revised: 23 July 2021 Accepted: 19 August 2021

Published: 16 September 2021

\section{Keywords}

Corona-virus

Bank performance

Stock price

Equity valuation

Pandemic

Nigeria.

JEL Classification

E58; G2 1; L10.

\section{ABSTRACT}

This study analyzes the effects of COVID-19 on the managerial efficiency of commercial banks in Nigeria by analyzing secondary data relating to five (5) sampled commercial banks, the stocks of which are currently traded on the country's equity market. The five banks were purposely selected, and the secondary data obtained were analyzed using descriptive and diagnostic tests, along with the structural equation model and regression technique. The results of this analysis indicate that the outbreak of COVID-19 significantly influenced the managerial efficiency of the five banks studied here. Given this result, we recommend that banks should continually develop and improve on the level of e-channel penetration by customers, as this will largely keep banking transactions from being disrupted by shocks - whether external or internal. Also, the country's apex bank and other regulatory bodies should ensure that the peculiarities of Nigeria's economy and markets are clearly understood, so that the design and implementation of policies and strategies meant to cushion the effects of perceived external threats (such as a pandemic) on banks and the economy as a whole will be purposeful and effective.

Contribution/Originality: This study contributes the first empirical analysis in the Nigerian context that uses weekly stock price data, reported COVID-19 cases and the lockdown policy to address the impact of the COVID-19 pandemic on the managerial efficiency of banks.

\section{INTRODUCTION}

The banking industry in Nigeria has gone through various developmental reforms that culminated in the banking consolidation led by Soludo in 2004. Since then, the banks that survived the consolidation have continued to grow and deliver strong returns to their respective stakeholders. Various studies, including Barros and Caporale (2012), Enyi (2007), Jeroh and Okoye (2015), and Okoye, Adetiloye, Erin, and Evbuomwan (2017) have analyzed the growth banks have undergone in the post-consolidation era. However, with the outbreak of COVID-19 in Wuhan (Hubei Province), China in December 2019 (Bahrini \& Filfilan, 2020; Kotishwar, 2020) and its global spread, economies and businesses around the world have felt the impact in different ways. While some telecom and related firms, like Zoom, MTN and Google, among others, are reported to have seen sustained growth and positive performance, the same can generally not be said of banks and stock markets, as they grappled with the new 
economic landscape occasioned by lockdowns and the social distancing introduced to curb the spread of COVID-19 (Anh \& Gan, 2021; He, Sun, Zhang, \& Li, 2020; Kotishwar, 2020). As reported by KPMG (2020) the effects on the banking sector are apparent in the form of government earnings pressure and debt sustainability issues, pressure on exchange rate stability, a decline in foreign portfolio investors and foreign direct investments which may lead to reduced access to credit from Global Financial Institutions, a multifaceted impact on domestic businesses and firms, and increased pressure on the income and consumption of households. Taken together, these factors certainly put pressure on banks to find new ways to grow their deposits, loan portfolios and other banking services with the hope of increasing their earnings and delivering positive returns to stakeholders. For this reason, this study is designed to assess management efficiency during the recent COVID-19 pandemic with its attendant curbing measures and government policies.

Notably, studies from outside Nigeria have maintained that following the wide spread of COVID-19 in early 2020, financial markets were forced into a tailspin, thus causing banks to be more vulnerable to ill effects when compared with other sectors (Acharya, Engle, \& Steffen, 2021; Aldasoro, Fender, Hardy, \& Tarashev, 2020; Haryanto \& Mawardi, 2021; KPMG, 2020). In the Nigerian context, despite theorization on the likely impact of COVID-19 on the performance of financial markets and banks generally, very few empirical studies have been conducted to ascertain the truth of these claims. Specifically, studies on the impact of the COVID-19 pandemic on banks have focused more on accounting measures of performance, whereas concerns regarding the pandemic's effect on managerial efficiency have so far received little or no attention in Nigeria.

This paper therefore aims to fill this knowledge gap by providing empirical evidence on how the level of managerial efficiency of Nigerian banks may have been affected by the COVID-19 pandemic. To achieve this aim, this study focuses on selected listed banks that are classified as top gainers in the banking sub-sector of the Nigerian Stock Exchange. These banks are Zenith Bank Plc, GTBank Plc, Access Bank Plc, First Bank of Nigeria Plc and United Bank For Africa Plc. The data used in this study spans the period from January $2^{\text {nd }}, 2020$, to March $5^{\text {th }}, 2021$ (a period of 64 weeks).

Given the study's thrust, our hypothesis is that:

The level of managerial efficiency of Nigerian banks was not significantly influenced by the outbreak of the COVID-19 pandemic.

\section{LITERATURE REVIEW}

The ability of commercial banks to mitigate possible cases of information asymmetry between lenders and borrowers while managing risks remains vital to their very existence. Certainly, the success or failure of a bank's management team also lies in their strategic decisions in the light of their respective stock price movements. This is why research evidence has shown that the movement of a company's stock prices remains a reliable measure of that company's level of managerial efficiency (Umar \& Musa, 2013). The prices of equity stocks vary daily in various stock markets. According to Oladiture and Agbaje (2019), based on the forces of supply and demand in relation to firm-specific characteristics, companies' stock prices tend to experience reasonable levels of appreciation during morning hours in certain periods of any given year. Despite this argument, there is yet no full scientific explanation of the exact trends and movements of companies' stock prices.

Arguably, prominent drivers of firms' stock prices include the supply and demand of stocks in identifiable markets, fundamental company-specific/internal factors, market trends, and other external factors including regulations, market and economic conditions, competition and environmental circumstances (Jeroh, 2020a; Vardar, 2013).

Soni (2012), however, maintains that the concept of managerial efficiency measures the level at which the management of a firm has effectively and efficiently managed the overall resources of the organization within a given period. For banks, the concept remains an important factor that guarantees sound functioning; it has a visible 
effect on the levels of year-end profitability figures, stock price movements, and declining levels of non-performing loans, among other financial ratios.

However, with the increasing levels of competition in virtually all banking sectors in economies across the globe, Yang and Liu (2012) argue that the concept of managerial efficiency and effectiveness has become the ideal banks must strive towards to improve their productivity while maximizing the overall wealth of their respective shareholders. With the recent deployment of several waves of technology and mobile banking apps, coupled with the recent stock market developments and the growing awareness and use of artificial intelligence tools and the like, our expectation is that external factors, such as the recent lockdown occasioned by the COVID-19 pandemic, should have little or no effect on banking activities/services and, by extension, banks' level of managerial efficiency as measured by their respective trends in stock price movement. Given this expectation, this study examines how well the management teams of commercial banks may have fared in harnessing their resources, as measured by the movement of their respective stock price during and after the restrictions imposed by the outbreak of COVID-19 in the country.

\subsection{COVID-19 Pandemic and Managerial Efficiency}

COVID-19 is a highly transmissible and pathogenic viral infection caused by severe acute respiratory syndrome coronavirus 2 (SARS-Cov-2) which is thought to have emerged in December 2019 in a large animal and seafood market in Wuhan, China (Shereen, Khan, Kazmi, Bashir, \& Siddique, 2020). Since the disease was first reported in China, it has rapidly spread across all countries in the world. Consequently, on January 30, 2020, the World Health Organization declared the disease a public health emergency of international concern (PHEIC) and subsequently characterized it as a pandemic in March 2020.

The index case of COVID-19 in Nigeria was reported in Lagos State on February 27, 2020, and the disease spread rapidly to other states in Nigeria. According to NCDC (2021), as of February 13, 2021, Nigeria has recorded 145,664 confirmed cases, 120,399 discharged cases and 1,747 deaths. The initial reaction from various tiers of the Nigerian government was to curb the spread of the virus through the imposition of lockdowns and curfews, which greatly affected the way businesses were conducted across Nigeria. A number of studies, including Baldwin (2020), BIS (2020), and Cheney, Hittner, Hogan, and Wang (2020), have suggested that the outbreak of COVID-19 has led to distortions in worldwide macro-economic variables, including employment, aggregate supply and demand, production, savings and investment, and domestic and international trade, which may deepen poverty and trigger a recession, thereby adversely affecting businesses across all sectors of the economy.

\subsection{Empirical Review}

Generally, in the Nigerian context, empirical studies linking the COVID-19 outbreak to the performance of banks, and specifically managerial efficiency or stock price movement, have remained scarce. However, evidence from the literature does suggest that a number of prior studies have examined either the effect of managerial efficiency on the performance ratios of firms, or the effect of the recent pandemic on general performance indices of economies, industries (including banks), and capital markets (Bahrini \& Filfilan, 2020; Fousekis, Kourtesi, \& Polymeros, 2014; He et al., 2020; Lee \& Lu, 2021; OZYESIL, 2021).

Dasgupta and Nath (2017) examined the managerial efficiency of selected banks in India with the aim of framing a robust comparative assessment of the level of managerial efficiency of the sampled banks. Relevant secondary data of the sampled banks were obtained from the Capitaline database for a period covering the third quarter of 2002 to the end of the fourth quarter of 2016. Their analysis was carried out using several measures of central tendencies, along with one-tailed and two-tailed t-tests. The Jarque Bera test for normality was also conducted along with the test of the study's hypotheses. The findings proved, among others, the significance of women-led banks in India with huge participation in advances and deposits. 
In a similar study, Bahrini and Filfilan (2020) examined data from GCC countries to assess the impact the COVID-19 pandemic (as measured by the number of confirmed cases and deaths) may have had on stock market returns. The data analyzed were secondary in nature and covered a 3-month period (April 1, 2020 - June 26, 2020. Analysis using a panel regression approach produced documentary evidence confirming that stock markets within the GCC countries reacted negatively and significantly to the recorded number of confirmed COVID-19 deaths, whereas the relationship between confirmed cases and stock market returns remained insignificant. Specifically, the study clearly demonstrated that the average trend of movement in stock market returns declined in response to an increase in the number of confirmed COVID-19 deaths. This finding thus supports Aldasoro et al. (2020) assertion that COVID-19 had obvious negative implications for the cost of banks' funds by pushing the costs higher than normal levels.

Barua and Barua (2021) studied the implications of COVID-19 for banks in Bangladesh, using firm value, capital adequacy and interest income (under different non-performing loan scenarios) in a scenario-based quantitative approach to a stress test designed by the Bangladesh apex bank. The study found that all banks in Bangladesh will experience a fall in risk-weighted asset value, capital adequacy ratios and net interest income.

Additionally, Phuong (2021) analyzed the response that firms within the Vietnamese banking sector displayed to 3 lockdown announcements in 2020 during the height of the COVID-19 epidemic in the country. Secondary data were obtained and analyzed using appropriate statistical tools. The results indicate that abnormal returns were found around the period of the lockdown notifications. Stock prices were observed to deviate from their fair values while accumulated abnormal returns were found to be positive and statistically significant.

\section{METHODS}

This study relies on a quantitative design and secondary data obtained from the databases of the Nigerian Stock Exchange and the country's Centre for Disease Control (where applicable) during the relevant period. The data on managerial efficiency - here measured as the ability of management to harness their resources effectively and efficiently, as portrayed by movements in the stock prices of their respective banks - were collated from the database of the Nigerian Stock Exchange, while data on the reported cases of COVID-19 were obtained from the database and published reports of the Nigerian Centre for Disease Control (NCDC). The collated stock price data related to a sample of five (5) banks over a period of 64 weeks spanning from January 2, 2020, to March 5, 2021. Analysis was carried out by means of descriptive statistics and inferences were made from the results of structural equation modeling and multiple regression. To ascertain the nature and relevance of the data to the study, selected diagnostic tests were also conducted. Notably, the analyses in this study were based on an econometric model that explains how COVID-19 affects managerial efficiency, as presented in Equation 1.

$$
\text { Managerial Efficiency of Banks }=f(\text { COVID-19 Pandemic) }
$$

Specifically, the above model is applied using Equation 2 and Equation 3, such that MEff represents the dependent variable and COVID-19 the independent variable, as proxied by $\mathrm{COV}_{\text {cases }}$ and $\mathrm{COV}_{\text {lock}}$.

$$
\begin{aligned}
M E f f_{i t} & =f(C O V I D-19) \\
M E f f_{i t} & =\beta_{o}+\beta_{i} C O V_{\text {cases }}+\beta_{2} C O V_{\text {lock }}+\mathrm{U}_{u t}
\end{aligned}
$$

In addition to the above, equation level models were designed for each of the sampled banks, as indicated in Equations 4-8. In Equations 4, 5, 6, 7, and 8, we present the models that express the link between the proxies for

\begin{tabular}{|c|c|c|}
\hline ZenMEff $f_{w t}$ & $=$ & $\beta_{o}+\beta_{l} C O V_{\text {cases }}+\beta_{2} C O V_{\text {lock }}+\mathrm{U}_{\text {wut }}$ \\
\hline GTBMEff $w t$ & $=$ & $\beta_{o}+\beta_{l} C O V_{\text {casses }}+\beta_{2} C O V_{\text {lock }}+\mathrm{U}_{u t}$ \\
\hline AccMEff $f_{w t}$ & $=$ & $\beta_{o}+\beta_{1} C O V_{\text {cases }}+\beta_{2} C O V_{\text {lock }}+\mathrm{U}_{\text {wut }}$ \\
\hline FbnMEff $f_{w}$ & $=$ & $\beta_{o}+\beta_{1} C O V_{\text {cases }}+\beta_{2} C O V_{\text {lock }}+\mathrm{U}$ \\
\hline
\end{tabular}
the independent variables and the measures of managerial efficiency of the sampled banks. The models and variable descriptions are thus: 


$$
\operatorname{UbaMEff}_{\text {wt }} \quad=\quad \beta_{o}+\beta_{t} C O V_{\text {cases }}+\beta_{2} C O V_{\text {lock }}+\mathrm{U}_{\text {wut }}
$$

Where:
MEff = Managerial Efficiency (measured as the ability of management to harness their resources effectively and efficiently, as portrayed by movements in the stock prices).
ZenMEff $_{\mathrm{wt}}=\quad$ Managerial Efficiency of Zenith Bank in week $\mathrm{t}$ (measured as the average weekly share price of Zenith Bank in week $t$ ).
GtbMEff $_{\mathrm{wt}}=$ Managerial Efficiency of GTBank in week $t$ (measured as the average weekly share price of GTBank in week t).
AccMEff $_{\mathrm{wt}}=\quad$ Managerial Efficiency of Access Bank in week $t$ (measured as the average weekly share price of Access Bank in week $\mathrm{t}$ ).
FbnMEff $_{\mathrm{wt}}=\quad$ Managerial Efficiency of First Bank of Nigeria in week $t$ (measured as the average weekly share price of First Bank in week $t$ ).
UbaMEff $_{\mathrm{wt}}=$ Managerial Efficiency of United Bank for Africa in week $t$ (measured as the average weekly share price of United Bank for Africa in week $t$ ).
$C O V_{\text {cases }}=$ The number of COVID-19 cases reported by NCDC in week $t$.
$\mathrm{COV}_{\text {lock }}=$ The period(s) of lockdown during the COVID-19 pandemic (measured by dummy variable o for weeks of total lockdown, 1 for weeks of partial lockdown, and 2 for weeks without lockdown restrictions).

\section{RESULTS AND DISCUSSION}

\subsection{Descriptive Statistics and Diagnostic Tests}

The result of the descriptive statistics for the entire data set across all panels is summarized in Table 1.

Table-1. Tabulated results for summary statistics

\begin{tabular}{c|c|c|c|c|c}
\hline Variables & Mean & $\begin{array}{c}\text { Standard } \\
\text { Dev. }\end{array}$ & $\begin{array}{c}\text { Minimum } \\
\text { Value }\end{array}$ & $\begin{array}{c}\text { Maximum } \\
\text { Value }\end{array}$ & No. of Observations \\
\hline ZenMEff & 19.43 & 4.29 & 11.59 & 26.71 & 64 \\
\hline GtbMEff & 27.61 & 5.45 & 17.44 & 40.33 & 64 \\
\hline AccMEff & 7.75 & 1.45 & 5.83 & 11.65 & 64 \\
\hline FbnMEff & 5.94 & 1.19 & 3.90 & 9.03 & 64 \\
\hline UbaMEff & 7.19 & 1,25 & 4.84 & 11.37 & 64 \\
\hline COV $_{\text {cases }}$ & 2452.50 & 2837.60 & 0.00 & 10793 & 64 \\
\hline COV $_{\text {Lock }}$ & 1.27 & 0.88 & 0.00 & 2 & \\
\hline
\end{tabular}

Table 1 presents a summary of the results of the descriptive statistics of the study's variables. The mean values of the managerial efficiency of Zenith Bank, GTBank, Access bank, FBN and UBA, as portrayed by the value of their respective average share prices, are 19.43, 27.61, 7.75, 5.94, and 7.19, respectively, with standard deviations of $4.29,5.45,1.45,1.19$, and 1.25 , respectively. The range of standard deviations recorded for the dependent variables is indicative of low variability of share price movement over the study period. This trend differs in the case of $\mathrm{COV}_{\text {Cases }}$ whose mean value is $2,452.50$, with a corresponding standard deviation of 2,837.60. The comparably high standard deviation suggests a marked difference in the number of reported cases of COVID-19 in some weeks during the period.

\subsection{Correlation Analysis}

The results of the correlation analysis are presented in Table 2. One clear observation that can be made from the table is that all the dependent variables recorded positive correlations. Also, the correlation coefficient between the two explanatory variables $\left(\mathrm{COV}_{\text {Cases }}\right.$ and $\left.\mathrm{COV}_{\text {Lock }}\right)$ stood at 0.0847 . Since this value is below the threshold of 
0.70 or 0.80 , we argue, in line with Jeroh (2020a) and Jeroh (2020b), that the model is a good fit, because there are no signs of multi-collinearity among the independent variables.

Table-2. Correlation result.

\begin{tabular}{c|c|c|c|c|c|c|c}
\hline Variables & ZenMEff & GtbMEff & AccMEff & FbnMEff & UbaMEff & COVcases & COV $_{\text {Lock }}$ \\
\hline ZenMEff & 1.0000 & & & & & & \\
\hline GtbMEff & 0.8859 & 1.0000 & & & & & \\
\hline AccMEff & 0.6864 & 0.8091 & 1.0000 & & & & \\
\hline FbnMEff & 0.8906 & 0.9487 & 0.8494 & 1.0000 & & & \\
\hline UbaMEff & 0.8384 & 0.9215 & 0.8761 & 0.9712 & 1.0000 & & \\
\hline COV $_{\text {cases }}$ & 0.5047 & 0.2867 & 0.1224 & 0.4019 & 0.4053 & 1.0000 & \\
\hline COV $_{\text {Lock }}$ & 0.7063 & 0.6447 & 0.6115 & 0.5774 & 0.5331 & 0.0847 & 1.0000 \\
\hline
\end{tabular}

4.3. Multivariate Test for Normality and Compound Symmetry

Table-3. Result of the multivariate test for normality \& compound symmetry.

\begin{tabular}{l|c|c|c}
\hline \multicolumn{1}{l|}{ Test For Normality of Residuals } & \multicolumn{2}{c}{ Test For Compound Symmetry } \\
\hline Doornik-Hansen Chi2(18) & Prob $>$ chi2 & Lawley chi2(20) & Prob $>$ chi2 \\
\hline $\mathbf{1 0 9 . 7 4 9}$ & $0.0000^{*} *$ & 260.05 & $0.0000^{*} *$ \\
\hline Note: **significant at $1 \%$.
\end{tabular}

To ascertain the extent of distribution of the residuals and to check for the presence or absence of outliers in the collated data, we conducted a multivariate test for normality and compound symmetry using the DoornikHansen test for normality, since the dependent variable under consideration cuts across more than one bank. The obtained results are that the test for normality produced 109.749, with 0.0000 for the Chi2(14) and the probability value respectively. This means that the residuals were normally distributed, thereby satisfying one of the conditions for using the regression technique. Additionally, the result of the Lawley test for compound symmetry, which tests the equality of the values obtained for the correlation matrix, showed that all correlations are equal. This further confirms that the data for this study meets the minimum requirements to conduct a regression analysis.

\subsection{Hypothesis Testing}

To test our hypothesis, the data on each banks' managerial efficiency, as measured by the respective trends of their share price movement, were regressed against the variables describing the status of the COVID-19 pandemic (number of reported cases and lockdown policy) using the structural equation modeling approach. Table 4 presents the results of this approach.

As evinced in Table 4, the coefficients of 0.0006772 and 3.267356 for $\operatorname{COV}_{\text {cases }}$ and $\mathrm{COV}_{\text {lock}}$, respectively, suggest a positive association between the COVID-19 pandemic and the level of managerial efficiency displayed by Zenith Bank. The $Z_{\text {stat }}$ values of 6.50 and 9.70 with p-values of 0.000 in both cases imply that ZenMEff (the managerial efficiency of Zenith bank) was significantly influenced by the occurrence of the pandemic. The number of weekly reported cases of COVID-19 significantly impacted the movement in share prices of Zenith Bank. Similarly, the lockdown policy was also found to significantly impact the average weekly share/equity price of Zenith Bank.

Furthermore, a similar trend to that exhibited by Zenith Bank can be observed in the case of GTBank, where the coefficients for $\mathrm{COV}_{\text {cases }}$ and $\mathrm{COV}_{\text {lock }}$ were 0.0004486 and 3.879521 , respectively, signifying a positive association between the managerial efficiency of GTBank and the COVID-19 pandemic. The $Z_{\text {stat }}$ values of 2.56 and 6.84 and the reported p-values of 0.010 and 0.000 for $\mathrm{COV}_{\text {cases }}$ and $\mathrm{COV}_{\text {lock}}$, respectively, mean that the number of COVID-19 cases that were recorded on a weekly basis as well as the lockdown policy both significantly impacted on the share price movement of GTBank. 
International Journal of Management and Sustainability, 202 1, 10(3): 69-78

Table-4. Summary of SEM Estimation Output

\begin{tabular}{|c|c|c|c|}
\hline Sample & Statistics & COVCases & COVLock \\
\hline \multirow{4}{*}{ ZenMEff } & Coeff: & 0.0006772 & 3.267356 \\
\hline & Std.Err. & 0.0001042 & 0.3369623 \\
\hline & Z & $6.50^{* * *}$ & $9.7 \mathrm{O}^{* * *}$ \\
\hline & $\mathrm{P}>|\mathrm{z}|$ & 0.000 & 0.000 \\
\hline \multirow{4}{*}{ GtbMEff } & Coeff: & 0.0004486 & 3.879521 \\
\hline & Std.Err. & 0.0001753 & 0.5670987 \\
\hline & $Z$ & $2.56^{* * *}$ & $6.84^{* * *}$ \\
\hline & $\mathrm{P}>|\mathrm{z}|$ & 0.010 & 0.000 \\
\hline \multirow{4}{*}{ AccMEff } & Coeff: & 0.0000364 & 1.002877 \\
\hline & Std.Err. & 0.0000506 & 0.1637504 \\
\hline & $\mathrm{Z}$ & $0.72^{* *}$ & $6.12^{* *}$ \\
\hline & $\mathrm{P}>|\mathrm{z}|$ & 0.472 & 0.000 \\
\hline \multirow{4}{*}{ FbnMEff } & Coeff: & 0.0001495 & 0.7442316 \\
\hline & Std.Err. & 0.0000388 & 0.1254934 \\
\hline & Z & $3.85^{* *}$ & $5.93^{* *}$ \\
\hline & $\mathrm{P}>|\mathrm{z}|$ & 0.000 & 0.000 \\
\hline \multirow{4}{*}{ UbaMEff } & Coeff: & 0.0001598 & 0.715831 \\
\hline & Std.Err. & 0.0000423 & 0.1367386 \\
\hline & Z & $3.78^{* *}$ & $5.24^{* * *}$ \\
\hline & \begin{tabular}{l|l|}
$P>$ & $z$ \\
\end{tabular} & 0.000 & 0.000 \\
\hline $\operatorname{chi} 2(10)=455.08$ & \multicolumn{3}{|c|}{ Prob $>$ chi $2=0.0000$} \\
\hline
\end{tabular}

With respect to the result for Access bank, the $Z_{\text {stat }}$ values obtained for $\operatorname{COV}_{\text {cases }}$ and $\operatorname{COV}_{\text {lock }}$ were 0.72 and 6.12, respectively, with corresponding p-values of 0.472 and 0.000 , respectively. The implication of this result is that the number of weekly reported cases of COVID-19 did not exert significant influence on the managerial efficiency of Access bank, as measured by their share price movement. In contrast, with a $Z_{\text {stat }}$ of 6.12 (p-value = $0.000<0.05)$, the lockdown policy was found to exert a significant and positive influence on the managerial efficiency of Access bank (as measured by the overall average weekly share price trend).

The results with regard to First Bank, however, showed that the $Z_{\text {stat }}$ values for $\operatorname{COV}_{\text {cases }}$ and $\operatorname{COV}_{\text {lock }}$ were 3.85 and 5.93, respectively, with p-values of 0.000 in both cases. This result is consistent with the above-mentioned positions of Zenith and GTBank, in that the weekly number of COVID-19 cases and the lockdown policy both had a significant effect on the managerial efficiency of First Bank.

Additionally, data from the $5^{\text {th }}$ bank (UBA Plc.) further supports the observed trend. The $Z_{\text {stat }}$ values were 3.78 and 5.24 for $\mathrm{COV}_{\text {cases }}$ and $\mathrm{COV}_{\text {lock }}$ respectively. In both cases, the p-values obtained were 0.0oo. Further, the coefficients for $\mathrm{COV}_{\text {cases }}$ and $\mathrm{COV}_{\text {lock }}$ were calculated as 0.0001598 and 0.715831 , respectively, suggesting the existence of positive relationship between the dependent and explanatory variables. In the case of UBA, the weekly number of recorded cases of COVID-19 and the lockdown policy again both significantly influenced the managerial efficiency of the bank.

Finally, considering the results of the overall model, since the chi2(10) was calculated as 455.08 (Prob $>$ chi2 $=$ $0.0000)$ the hypothesis that the level of managerial efficiency of Nigerian banks was not significantly influenced by the COVID-19 pandemic is thus rejected. This outcome is consistent with the findings of Anh and Gan (2021) whose study in the Vietnamese context revealed that periods of lockdown significantly and positively influenced stock performance/returns. Based on the obtained results, we argue that the managerial efficiency of Nigerian banks significantly improved during the COVID-19 pandemic. This is likely the result of the stringent measures taken by the country's stock exchange and banks during the lockdown period to ensure that banking and stock market activities were not disrupted. Specifically, banking operations were ongoing during the lockdown period as bank employees were working remotely while simultaneously encouraging bank customers to continually patronize various banking APPs and e-channels/platforms to carry out transactions. Similar strategies were deliberately adopted by the country's stock exchange, so that stockbrokers were able to transact electronically without having 
to be physically present at the Exchange House. Instructions from clients were obtained through electronically driven means, thus permitting the continued smooth purchase and sale of stocks throughout the lockdown.

\section{CONCLUSION, RECOMMENDATIONS FOR FUTURE RESEARCH}

Previous studies have explicitly examined the movements in firms' share prices and the possible determinants of bank performance over time. The results of these studies have advanced several factors that have been shown to drive bank performance, share price trends and bank efficiency. With the outbreak of the COVID-19 pandemic in 2020, research efforts have specifically attempted to ascertain whether the pandemic has distorted economic and market indices. Interestingly, although prior studies had examined aggregate data from identified sub-sectors, including banks, we found that the effects the pandemic may have had on individual firms (in our case, commercial banks) had not been investigated. This inspired the current study which, using relevant COVID-19 and stock market data, set out to examine by empirical means the relationship between the COVID-19 pandemic and the managerial efficiency of selected commercial banks in Nigeria. Both descriptive and diagnostic tests were conducted before testing the specific hypothesis.

Overall, we can conclude that the COVID-19 pandemic exerted significant influence on the managerial efficiency of commercial banks in Nigeria. Based on this conclusion, we recommend as follows:

1. The country's apex bank and other regulatory bodies should ensure that the peculiarities of Nigeria's economy and markets should at all times be clearly understood, such that the design and implementation of policies and strategies meant to cushion the effects of perceived external threats (such as a pandemic) on banks and the economy as a whole will be purposeful and effective.

2. Banks should continually develop and improve on the level of e-channel penetration by customers. This will largely keep banking transactions from being disrupted by shocks - whether external or internal.

3. The banks' management teams should develop strategies to help cushion the effects of potential future external threats to their operations and resources. The need to always anticipate potential threats and devise mechanisms to cushion their effects on the overall organization cannot be over-emphasized.

4. Banks should leverage technologies that enhance their abilities to conduct their tasks digitally and remotely.

Future research should examine the degree of responsiveness of other firms and managerial attributes to the recent pandemic (COVID-19) as it applies to banks and other corporate entities. The outcome of such investigations would broaden the understanding of the direction of the relationship between the COVID-19 pandemic and performance/managerial indices among firms, thereby creating a foundation for assessing the practical applicability of policies and strategic choices.

Funding: This study received no specific financial support.

Competing Interests: The authors declare that they have no competing interests.

Acknowledgement: All authors contributed equally to the conception and design of the study

\section{REFERENCES}

Acharya, V. V., Engle, I. R. F., \& Steffen, S. (2021). Why did bank stocks crash during covid-19? NBER Working Paper No. 28559 .

Aldasoro, I., Fender, I., Hardy, B., \& Tarashev, N. (2020). Effect of covid-19 on the banking sector: The market's assessment (pp. 1-9). BIS Bulletin No. 12.

Anh, D. L. T., \& Gan, C. (2021). The impact of the COVID-19 lockdown on stock market performance: Evidence from Vietnam. Journal of Economic Studies, 48(4), 836-85 1. Available at: https://doi.org/10.1 108/JES-06-2020-0312.

Bahrini, R., \& Filfilan, A. (2020). Impact of the novel coronavirus on stock market returns: Evidence from GCC countries. Quantitative Finance and Economics, 4(4), 640-652. Available at: https://doi.org/10.3934/qfe.2020029. 
Baldwin, R. (2020). Economics in the time of covid-19. London: CEPR Press.

Barros, C. P., \& Caporale, G. M. (2012). Banking consolidation in Nigeria, 2000-2010. Journal of African Business, 13(3), $244-252$. Available at: https://doi.org/10.1080/15228916.2012.727756.

Barua, B., \& Barua, S. (2021). COVID-19 implications for banks: Evidence from an emerging economy. SN Business \& Economics, 1(1), 1-28. Available at: https://doi.org/10.1007/s43546-020-00013-w.

BIS. (2020). Measures to reflect the impact of covid-19. Basel committee on banking supervision. Basel, Switzerland: Bank for International Settlements (BIS).

Cheney, J., Hittner, R., Hogan, C., \& Wang, P. (2020). COVID-19 impact on bank liquidity risk management and response. . NewYork: Deloitte \& Touche LLP.

Dasgupta, M., \& Nath, S. (2017). Managerial efficiency in Indian private sector banks with women CEOs: An empirical study on ICICI and Axis Bank. Amity Journal of Finance, 2(1), 56-72.

Enyi, E. P. (2007). Bank's consolidation in Nigeria: A synergistic harvest. Unpublished. Retrieved from: http://eprints.covenantuniversity.edu.ng/111/1/BANKS-CONSOLIDATION-IN-NIGERIA.pdf.

Fousekis, P., Kourtesi, S., \& Polymeros, A. (2014). Assessing managerial efficiency on olive farms in Greece. Outlook on Agriculture, 43(2), 123-129. Available at: https://doi.org/10.5367/oa.2014.0162.

Haryanto, A. M., \& Mawardi, W. (2021). Impact of COVID-19 news on performance of Indonesia stock market. Universal Journal of Accounting and Finance, 9(2), 226 - 231. Available at: https://doi.org/10.13189/ujaf.2021.0902 12.

He, P., Sun, Y., Zhang, Y., \& Li, T. (2020). COVID-19's impact on stock prices across different sectors - an event study based on the Chinese stock market. Emerging Markets Finance and Trade, 56(10), 2198-2212. Available at: https://doi.org/10.1080/1540496X.2020.1785865.

Jeroh, E. (2020a). Internal determinants of share price movements among listed companies in Nigeria: Does gender diversity in boardroom matter? Management Journal, 60, 97 - 108. Available at: https://doi.org/10.17576/pengurusan-2020-60-08.

Jeroh, E. (2020b). Corporate financial attributes and the value of listed financial service firms: The Nigerian evidence. Academy of Accounting and Financial Studies Journal, 24(2), 1-13.

Jeroh, E., \& Okoye, E. (2015). Impact assessment of bank consolidation on the performance of commercial banks in Nigeria. Acta Universitatis Danubius Oeconomica, $11(5), 30-44$.

Kotishwar, A. (2020). Impact of COVID-19 pandemic on stock market with reference to select countries-a study. Academy of Accounting and Financial Studies Journal, 24(4), 1-9.

KPMG. (2020). The twin shocks (covid 19 pandemic $\&$ oil price war) and implications for the banking sector. Analysis of covid 19 and oil price war impacts and potential mitigating measures. Lagos: KPMG Advisory Services.

Lee, K., \& Lu, S. (2021). The impact of covid-19 on the stock price of socially responsible enterprises: An empirical study in Taiwan stock market. International Journal of Environmental Research and Public Health, 18, 1398. Available at: https://doi.org/10.3390/ijerph18041398.

NCDC. (2021). Covid-19 in Nigeria. Retrieved from www.covid-19.ncdc.gov.ng.

Okoye, L. U., Adetiloye, K. A., Erin, O., \& Evbuomwan, G. O. (2017). Impact of banking consolidation on the performance of the banking sector in Nigeria. The Journal of Internet Banking and Commerce, 22(1), 1-16.

Oladiture, E. O., \& Agbaje, W. H. (2019). Return on assets and market stock prices of deposit money banks in Nigeria. Accounting and Taxation Review, 3(3), 78-90.

OZYESIL, M. (2021). Comparison of technical and fundamental analysis trading disciplines on portfolio performance: Short and long term backtest analysis on Borsa Istanbul national stock indices. Journal of Contemporary Research in Business, Economics and Finance, 3(3), 128-143. Available at: https://doi.org/10.33094/26410265.2021.33.128.143.

Phuong, 1. C. M. (2021). How COVID-19 impacts Vietnam's banking stocks: An event study method. Banks and Bank Systems, 16(1), 92-102. Available at: http://dx.doi.org/10.21511/bbs.16(1).2021.09. 
Shereen, M. A., Khan, S., Kazmi, A., Bashir, N., \& Siddique, R. (2020). COVID-19 infection: Origin, transmission, and characteristics of human coronaviruses. Journal of Advanced Research, 24, 91-98. Available at: https://doi.org/10.1016/j.jare.2020.03.005.

Soni, R. (2012). Managerial efficiency - key driver towards the profitability of Indian commercial banks in turbulent time. International Journal of Applied Research \& Studies, 1(2), 1-16.

Umar, M. S., \& Musa, T. B. (2013). Stock prices and firm earnings per share in Nigeria. Journal of Research In National Development, $11(2), 187-192$.

Vardar, G. (2013). Efficiency and stock performance of banks in transition countries: Is there a relationship? International Journal of Economics and Financial Issues, 3(2), $355-369$.

Yang, C., \& Liu, H.-M. (2012). Managerial efficiency in Taiwan bank branches: A network DEA. Economic Modelling, 29(2), 450461. Available at: https://doi.org/10.1016/j.econmod.2011.12.004.

Views and opinions expressed in this article are the views and opinions of the author(s), International Journal of Management and Sustainability shall not be responsible or answerable for any loss, damage or liability, etc. caused in relation to/arising out of the use of the content. 